\title{
HIGH PREVALENCE OF THE SIMULTANEOUS EXCRETION OF POLYOMAVIRUSES JC AND BK INTHE URINE OF HIV-INFECTED PATIENTS WITHOUT NEUROLOGICAL SYMPTOMS IN SÃO PAULO, BRAZIL
}

\author{
Luiz Henrique da Silva NALI(1), Cristiane de Campos CENTRONE(1), Paulo Roberto Palma URBANO(1), Augusto César PENALVA-DE-OLIVEIRA(2), \\ Jose Ernesto VIDAL(2), Erique Peixoto MIRANDA(3), Claudio Sérgio PANNUTI(1) \& Maria Cristina Domingues da Silva FINK(1)
}

\begin{abstract}
SUMMARY
Objective: To evaluate the prevalence of the urinary excretion of BKV and JCV in HIV-infected patients without neurological symptoms. Methods: Urine samples from HIV-infected patients without neurological symptoms were tested for JC virus and BK virus by PCR. Samples were screened for the presence of polyomavirus with sets of primers complementary to the early region of JCV and BKV genome (AgT). The presence of JC virus or BK virus were confirmed by two other PCR assays using sets of primers complementary to the VP1 gene of each virus. Analysis of the data was performed by the Kruskal-Wallis test for numerical data and Pearson or Yates for categorical variables. Results: A total of 75 patients were included in the study. The overall prevalence of polyomavirus DNA urinary shedding was 67/75 (89.3\%). Only BKV DNA was detected in 14/75 (18.7\%) urine samples, and only JCV DNA was detected in 11/75 (14.7\%) samples. Both BKV and JCV DNA were present in 42/75 (56.0\%) samples. Conclusion: In this study we found high rates of excretion of JCV, BKV, and simultaneous excretion in HIV+ patients. Also these results differ from the others available on the literature.
\end{abstract}

KEYWORDS: JC virus DNA; BK virus DNA; Simultaneous excretion; HIV-infected.

\section{INTRODUCTION}

$\mathrm{JC}$ virus (JCV) and BK virus (BKV) are ubiquitous in the human population $^{9,29}$. Serum-prevalence studies have shown that approximately 70 to $80 \%$ of healthy individuals have antibodies against BKV and $\mathrm{JCV}^{3,11,19,20}$. In immunocompromised individuals, JCV is associated with Progressive Multifocal Leukoencephalopathy (PML), an often fatal disease of the central nervous system ${ }^{5,13}$, and with other neurological diseases (granule cell neuronopathy, encephalopathy and meningitis) ${ }^{39}$. In addition, $\mathrm{BKV}$ is associated with hemorrhagic cystitis in hematopoietic stem cell transplantation (HSCT) recipients and interstitial nephropathy in kidney transplant recipients and has recently also been shown to be associated with neurologic complications ${ }^{26,41}$. After primary infection, both viruses establish a persistent infection in the kidneys and may be excreted in the urine ${ }^{15,22}$.

The prolonged immunosuppression associated with AIDS contributes to the high prevalence of reactivation of these viruses. There are few reports on the prevalence of the urinary excretion of JCV and BKV and the occurrence of simultaneous excretion in HIV-infected patients ${ }^{7,34}$.

Also, BKV and JCV have been gathering attention from scientists from different areas of the medicine due to its ability to infect and cause disease in patients with different kind of immunosuppression and patients treated with monoclonal antibody based therapies ${ }^{30}$.

The aim of this study was to evaluate the prevalence of the urinary excretion of BKV and JCV in HIV-infected patients without neurological symptoms.

\section{METHODS}

\section{Patients}

Study and urine samples: Urine samples were collected from 75 HIV-infected patients without any neurologic symptoms or a history of PML who were undergoing regular follow-up at the Outpatient Care Unit of the Instituto de Infectologia Emilio Ribas (IIER), São Paulo, Brazil. The study was approved by the Ethic Research Committee of the IIER. All patients signed an informed consent form.

Sample preparation: BKV and JCV DNA were extracted from $200 \mu \mathrm{L}$ urine samples using resin columns (QIAamp® DNA Blood Mini Kit, Qiagen, Germany) according to the manufacturer's instructions.

JCV and BKV DNA detection: All samples were initially screened

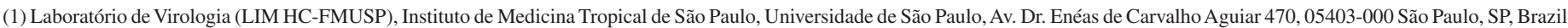

(2) Instituto de Infectologia Emílio Ribas, Av. Dr Arnaldo 165, São Paulo, SP, Brazil.

(3) Departamento de Moléstias Infecciosas e Parasitárias, Faculdade de Medicina da Universidade de São Paulo, Av. Dr. Enéas de Carvalho Aguiar 255, São Paulo, SP, Brazil.

Correspondence to: Maria Cristina Domingues da Silva FINK. Phone: +55 1130617020 ext 112. E-mail: crisfink@usp.br 
NALI, L.H.S.; CENTRONE, C.C.; URBANO, P.R.P.; PENALVA-DE-OLIVEIRA, A.C.; VIDAL, J.E.; MIRANDA, E.P.; PANNUTTI, C.S. \& FINK, M.C.D.S. - High prevalence of the simultaneous excretion of polyomaviruses JC and BK in the urine of HIV-infected patients without neurological symptoms in São Paulo, Brazil. Rev. Inst. Med. Trop. Sao Paulo, 54(4): $201-5,2012$.

using PCR according to protocol described by ARTHUR et al. ${ }^{4}$ and standardized by FINK et al. ${ }^{18}$. This PCR uses primers complementary to the early region of the polyomavirus genome that is shared by JCV and BKV (T antigen) (Table 1).

Table 1

Primers used for PCR

\begin{tabular}{lllc}
\hline Primer & $\begin{array}{l}\text { Viral } \\
\text { Region }\end{array}$ & Sequence & Reference \\
\hline PEP1 & AgT & AGTCTTTAGGGTCTTCTAC & $(4)$ \\
PEP2 & AgT & GGTGCCACCTATGGAACAG & $(4)$ \\
JLP-15 & VP1 (VJC) & ACAGTGTGGCCAGAATTCACTACC & $(1)$ \\
JLP-16 & VP1 (VJC) & TAAAGCCTCCCCCCCAACAGAAA & $(1)$ \\
BKV1 & VP1 (VBK) & GAAGTTCTAGAAGTTAAAACTGGG & $(25,31)$ \\
BKV2 & VP1 (VBK) & GTGGAAATTACTGCCTTGAATAGG & $(25,31)$ \\
\hline
\end{tabular}

The target sequence was amplified in a reaction with a final volume of $50 \mu \mathrm{L}$ containing $10 \mu \mathrm{L}$ of template, 10X PCR Buffer minus $\mathrm{Mg}, 200 \mu \mathrm{M}$ dNTPs, $0.5 \mu \mathrm{M}$ of each primer, $1.5 \mathrm{mM} \mathrm{MgCl}{ }_{2}$, and $2.5 \mathrm{U} /$ reaction Taq polymerase.

The reaction was submitted to an amplification of 40 cycles on a Perkin Elmer PTC 200 thermocycler as follows: $94{ }^{\circ} \mathrm{C}$ for 1.5 minutes, $55{ }^{\circ} \mathrm{C}$ for 1.5 minutes and $72{ }^{\circ} \mathrm{C}$ for two minutes. An initial DNA denaturation step for 10 minutes and a final extension step for seven minutes at $72{ }^{\circ} \mathrm{C}$ were also included. The length of the obtained fragment from the amplified samples was $173 \mathrm{bp}$.

All positive samples for AgT by PCR were submitted to two other PCR assays using sets of primers complementary to the genes that express the capsid protein, VP1, which differ between JCV and BKV, allowing the discrimination between these two polyomavirus.

For JCV, we adopted the protocol described by AGOSTINI et al. ${ }^{1}$ with some modifications. The cycle conditions were as follows: $95{ }^{\circ} \mathrm{C}$ for five minutes for initial DNA denaturation followed by 50 cycles of $95{ }^{\circ} \mathrm{C}$ for one minute, $63{ }^{\circ} \mathrm{C}$ for 1.5 minutes, and $72{ }^{\circ} \mathrm{C}$ for one minute and then $72{ }^{\circ} \mathrm{C}$ for 10 minutes for a final extension step. The length of the obtained fragment from the amplified samples was $215 \mathrm{bp}$.

For BKV, we adopted the protocol described by KRUMBHOLZ et $a l .{ }^{31}$ with some modifications. The cycle conditions were as follows: $94^{\circ} \mathrm{C}$ for five minutes for initial DNA denaturation followed by 45 cycles of $95^{\circ} \mathrm{C}$ for one minute, $63{ }^{\circ} \mathrm{C}$ for 1.5 minutes, and $72{ }^{\circ} \mathrm{C}$ for one minute and then $72{ }^{\circ} \mathrm{C}$ for 10 minutes for a final extension step. The length of the obtained fragment from the amplified samples was $353 \mathrm{bp}$.
PCR products were submitted to gel electrophoresis in a $1.5 \%$ agarose gel stained with ethidium bromide, and visualized after UV light exposition.

The original protocol was modified by adding glycerol (57\%), an adjuvant to improve the amplification of regions rich in $\mathrm{G}-\mathrm{C}^{12}$, and Cresol red $(2.5 \mu \mathrm{g} / \mu \mathrm{L})$ to dye the PCR product on the agarose ge ${ }^{24}$. For all PCR, positive and negative controls were added. The negative control consisted of the PCR mixture containing water instead of DNA template and to avoid contamination, the risks were eliminated by separating work areas for mixture preparation and PCR reactions.

The sets of primers used for PCR are presented in Table 1.

Statistical analysis: Analysis of the data was performed by the Kruskal-Wallis test with post hoc Dunn's test for numerical data and Pearson or Yates corrected Chi-squared for categorical variables. Values of $p<0.05$ were considered significant. SPSS 10.0 (IBM, Chicago, IL, USA) and GraphPad software (La Jolla, CA, USA) were used.

\section{RESULTS}

A total of 75 patients consented to participate in the study. The median age was 43 years old (range: 24 to 69 years old). Of these 75 patients, $49(65.3 \%)$ were men, and $26(34.7 \%)$ were women. The T cell CD4+ count was determined for $42 / 75$ patients and ranged from 12 to 1,179 cells $/ \mathrm{mm}^{3}$ (median, 250 cells $/ \mathrm{mm}^{3}$ ).

The overall prevalence of polyomavirus DNA urinary shedding was $67 / 75$ (89.3\%). Only BKV DNA was detected in 14/75 (18.7\%) urine samples, and only JCV DNA was detected in 11/75 (14.7\%) samples. Both BKV and JCV DNA were present in 42/75 (56.0\%) samples. No association was observed between the frequency of JCV and BKV virus shedding and the degree of immunodeficiency $(p=0.250)$.

Twenty-two women $(22 / 26,84.6 \%)$ and 45 men $(45 / 49,91.8 \%)$ presented viral excretion $(p=0.568)$. A higher percentage of positive samples was found among males than among females; however, this difference was not statistically significant (Table 2).

The median and interquartile ranges for age were not statistically different among the following groups: JCV $(43 \pm 12$, ranging from 30 to 54$)$, BKV (39.5 $\pm 14.5,24-53)$, simultaneous excretion $(44.5 \pm 12.75$, 29-69), positive ( $43 \pm 13,24-64)$, negative $(44 \pm 11.5,34-54)$ and total $(44 \pm 11.5,34-54)$. These comparisons were made using the KruskalWallis test $(p=0.203)$ with post hoc Dunn's multiple comparison test ( $p>0.05$ for all groups) (Fig. 1).

Table 2

Sex and positivity for polyomavirus BKV and JCV

\begin{tabular}{lcccc}
\hline Sex $(\mathrm{n})$ & $\mathrm{BKV}+(\%)$ & $\mathrm{JCV}+(\%)$ & Simultaneous excretion & Negative \\
\hline Male (49) & $9(18.3)$ & $8(16.3)$ & $28(57.0)$ & $4(8.1)$ \\
Female (26) & $5(19.2)$ & $3(11.5)$ & $14(53.8)$ & $4(15.4)$ \\
Total (75) & $14(18.7)$ & $11(14.7)$ & $42(56.0)$ & $8(10.7)$ \\
\hline
\end{tabular}




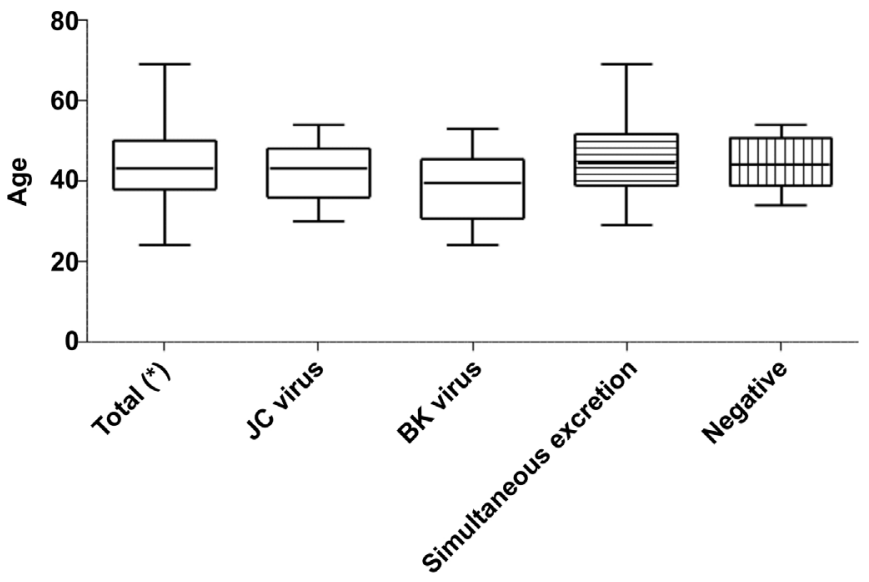

Fig. 1 - Box plots of the age ranges of patients excreting polyomaviruses. $(*)$ Total included positive (JC, BK and simultaneous) and negative samples.

We stratified the individuals by age and analyzed the number of positive cases for BKV and JCV. All subsets included a high number of positive individuals, and no significant difference in the proportion of positive individuals was observed between subsets (Table 3 ).

Table 3

Detection of JCV and BKV DNA and simultaneous excretion in HIV+ patients stratified by age

\begin{tabular}{lcccc}
\hline Age $(\mathrm{n})$ & $\mathrm{JC}(\%)$ & $\mathrm{BK}(\%)$ & Simultaneous $(\%)$ & Negative $(\%)$ \\
\hline $20-29(3)$ & 0 & $1(7.1)$ & $1(2.4)$ & 0 \\
$30-39(22)$ & $4(36.4)$ & $5(35.7)$ & $10(24)$ & $3(37.5)$ \\
$40-49(31)$ & $5(45.4)$ & $6(42.9)$ & $18(42.6)$ & $3(37.5)$ \\
$50-59(18)$ & $2(18.2)$ & $2(14.3)$ & $12(28.6)$ & $2(25)$ \\
$>59(1)$ & 0 & 0 & $1(2.4)$ & 0 \\
Total $(75)$ & $11 / 75(14.6)$ & $14 / 75(18.7)$ & $42 / 75(56)$ & $8 / 75(10.6)$ \\
\hline$p$ value & 0.888 & 0.212 & 0.511 & 0.949 \\
$\left(\right.$ Pearson $\left.\chi^{2}\right)$ & & & &
\end{tabular}

There was also no statistically significant difference in the medians and interquartile ranges of the T cell CD4+ count among all of the groups: JCV $(250 \pm 287.5$, ranging from 12 to 550$)$, BKV (339 \pm 377 , 160-700), simultaneous excretion (200 $\pm 416,46-1,179)$, positive (220 $\pm 404.5,12-1,179)$, negative $(539 \pm 600.5,72-1,016) ; p=0.602$ by the Kruskal-Wallis test with post hoc Dunn's multiple comparison test ( $p>$ 0.05 for all groups) (Fig. 2).

\section{DISCUSSION}

We observed that $42 / 75(56.0 \%)$ of the HIV-infected patients were excreting both JCV and BKV. There are few reports describing the simultaneous excretion of JCV and BKV in this patient population. BEHZAD-BEHBAHANI et al., reported a prevalence of simultaneous excretion of JCV and BKV of 5.9\% in HIV+ patients ${ }^{7}$. MARKOWITZ et al., observed concomitant excretion of JCV and BKV in four out of $122(3.3 \%)$ HIV-infected patients ${ }^{34}$. KNOWLES et al., also found low prevalence of the excretion of both viruses among HIV-infected patients $(11 / 81,13.2 \%)^{28}$.

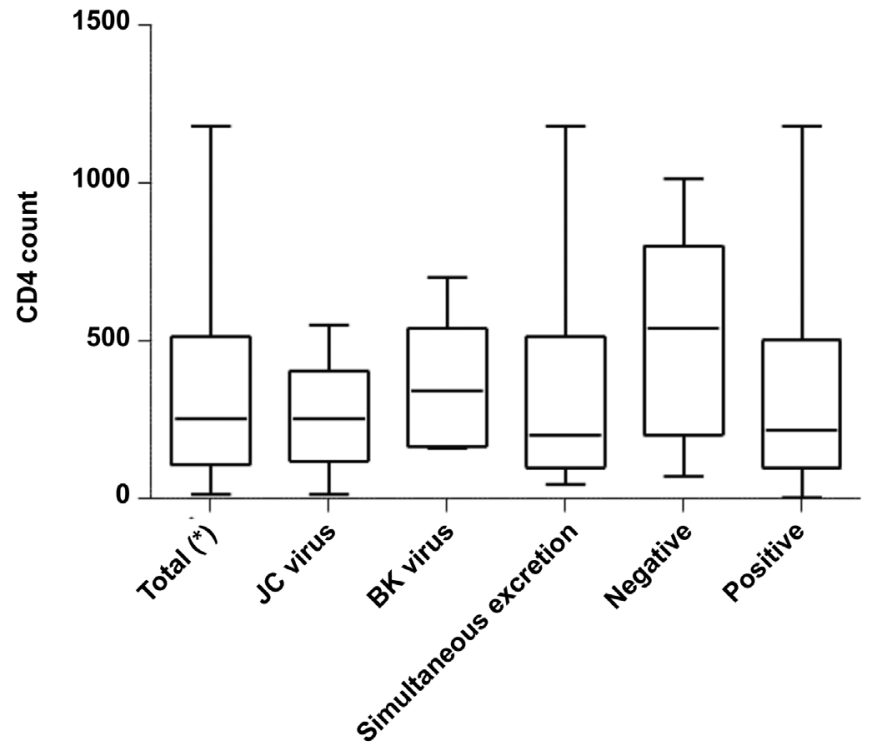

Fig. 2 - Box plots of the T cell CD4+ counts of patients excreting polyomaviruses. (*) Total included positive and negative excretion.

In our study the prevalence of BKV in patients who were shedding only BKV is similar to that found by MARKOWITZ et al. $^{34}$, and BEHZAD-BEHBAHANI et al. $^{7}$, ranging from $14 \%$ to $20 \%$. However, we must consider those patients with simultaneous excretion, which makes the frequency of BKV urinary shedding much higher, reaching $74.6 \%$. Also, a higher rate BKV shedding compared to JCV was reported in patients with other immunosuppressive conditions ${ }^{16}$.

Moreover, it is known that HIV can transactivate many viruses, among which the polyomavirus $\mathrm{JC}^{14}$. There are no data on the dispersion of JC virus and BK in our country, our results could reflect a high circulation of both viruses in the general population and its reactivation in the presence of immunodeficiency frames.

BKV has been shown to have the ability to cause encephalitis ${ }^{26,41}$ and hemorrhagic cystitis ${ }^{6}$ in AIDS patients, as well as urinary system diseases in HSCT and kidney transplant recipients.

PML, formerly a very rare disease ${ }^{10}$, is now one of the most frequent opportunistic diseases among AIDS patients ${ }^{2,8,23}$, and even after the introduction of Highly Active Anti-Retroviral Therapy (HAART), the incidence of PML did not decrease like that of other opportunistic infections ${ }^{2}$.

Including the patients who were excreting both viruses, $70 \%$ of patients of this study were JCV positive. This JCV prevalence is higher than that found in other similar studies ${ }^{7,21}$. The high rate of JCV urinary shedding could indicate a high exposure to the virus among this population.

We did not find any association between JCV and BKV urine excretion and the degree of immunodeficiency, as measured by the T CD4+ cell count. This finding has also been reported in previous studies. BEHZADBEHBAHANI et al. reported no statistically significant difference in the prevalence of JCV and BKV viruria between $\mathrm{HIV}+$ patients with $\mathrm{T}$ cell CD4+ counts lower and higher than 200 cells $/ \mathrm{mm}^{3(7)}$, and MATOS et al., 
NALI, L.H.S.; CENTRONE, C.C.; URBANO, P.R.P.; PENALVA-DE-OLIVEIRA, A.C.; VIDAL, J.E.; MIRANDA, E.P.; PANNUTTI, C.S. \& FINK, M.C.D.S. - High prevalence of the simultaneous excretion of polyomaviruses JC and BK in the urine of HIV-infected patients without neurological symptoms in São Paulo, Brazil. Rev. Inst. Med. Trop. Sao Paulo, 54(4): $201-5,2012$.

did not find any association between JCV shedding and the degree of immunodeficiency ${ }^{35}$. MARKOWITZ et al., also did not find any increase in the frequency of JCV in HIV-infected patients with different degrees of immunodeficiency but did find a correlation between BKV shedding and the degree of immunodeficiency: $8 \%$ of patients with T cell CD4+ counts higher than 500 cells $/ \mathrm{mm}^{3}$ shed BKV and $37.5 \%$ of patients with T cell $\mathrm{CD} 4+$ counts lower than 200 cells $/ \mathrm{mm}^{3}$ shed $\mathrm{BKV}^{34}$. The same finding was reported by KNOWLES et al., 1999, who found BKV DNA in only $9 / 40(22.5 \%)$ patients with T cell CD4+ counts higher than 200 cells $/ \mathrm{mm}^{3}$ and in $21 / 40(51.2 \%)$ patients with T cell CD4+ counts lower than 200 cells $/ \mathrm{mm}^{3}{ }^{328)}$. The prevalence of JCV urine shedding was not significantly associated with the degree of immunodeficiency.

In the present study, there was no association between JCV and BKV shedding and sex, $p=0.768$ (Table 2), in contrast to a previous study that reported a substantially higher shedding rate among male individuals ${ }^{35}$.

We observed a slightly higher frequency of the urinary shedding of both viruses in older individuals; however, the ages of the groups (JCV, BKV, simultaneous excretion and negative) were not significantly different (Table 2). This increase has been reported for JCV in an immunocompetent population, in which the older the population, the higher the frequency of JCV urinary shedding ${ }^{36,42}$. In an immunocompetent population $\mathrm{BK}$ virus did not show an increase in the frequency of shedding with age $\mathrm{e}^{36,42}$.

In immunocompetent populations from Asia and Europe, the prevalence of JCV urinary shedding was considerably higher than $\mathrm{BKV}^{17,27,35,37,40}$, but in HIV-positive patients, the urinary shedding of these viruses has not been well evaluated. SUNDSFJORD et al., found a higher number of BKV-positive than JCV-positive urine samples for $\mathrm{HIV}+$ patients, but this difference was not significant ${ }^{38}$.

Interestingly, we found that the prevalence of urinary shedding of $\mathrm{BKV}$ in our population was slightly higher than the JCV urinary shedding prevalence, but this difference was not statistically significant, probably due to the small number of samples after stratification by age and to the large number of positive samples in all age groups $(p=0.193)$.

Although the data found in this study, the following work has some limitations: the HIV, BKV and JCV load were not available. However, other studies found no direct association between HIV viral load and excretion of polyomavirus. MATOS et al., described that in HIV and JCV co-infected individuals, there was no statistical difference between HIV viral load and detection of JCV DNA in the urine. Also similar results were found, by LEDESMA et al., regarding BK detection and HIV viral load ${ }^{32}$.

Also this study does not have a control group. However a recent work published by MACHADO et al., 2011, found different rates of JCV and BKV urinary shedding in HIV+ children and non-infected children. In this study the BKV frequency was significantly higher in HIV infected patients in comparison of healthy subjects $(54.3 \% \text { vs. } 12.5 \%)^{33}$. However the age of the participants of this study is very different from ours, it was not possible to compare the two groups. The biological basis and the possible viral interactions associated with the high prevalence of co-infection have not been well described, also little is known about the shedding dynamics of these viruses in these population therefore, further studies should be done. In summary, in our study, we found high rates of urinary shedding of JCV (70.7\%) and BKV (74.7\%) in this HIV-infected patients group. In addition, we also found high rates of the simultaneous excretion of JCV and $\mathrm{BKV}(56 \%)$ in $\mathrm{HIV}+$ patients, a result that has not been reported before.

\section{RESUMO}

\section{Alta prevalência de excreção simultânea de poliomavírus JC e BK na urina de pacientes HIV+ sem sintomas neurológicos em São Paulo, Brasil}

Objetivo: Avaliar a prevalência de excreção urinaria de vírus JC (VJC) e vírus BK (VBK) em pacientes HIV+ sem sintomas neurológicos. Métodos: Amostras de urina de pacientes HIV+ sem sintomas neurológicos foram testados para a presença de VJC e VBK através da técnica de PCR. As amostras foram triadas para a presença de poliomavírus com par de primers complementares a região precoce do genoma do VBK e do VJC (AgT). A presença foi confirmada através de dois outros ensaios de PCR dirigidos a região do gene VP1 de ambos os vírus. A análise estatística foi realizada com auxílio do teste de Kruskal-Wallis para dados numéricos e Pearson ou Yater para variáveis categóricas. Resultados: Ao todo foram inclusos no estudo 75 pacientes. A prevalência geral de excreção de poliomavírus na urina foi de $67 / 75(89,3 \%)$. O DNA do vírus VBK foi detectado em $14 / 75(18,7 \%)$ das amostras de urina, e o DNA do VJC foi detectado em $11 / 75(14,7 \%)$ das amostras testadas. Ambos os vírus estavam presentes simultaneamente em 42/75 (56\%) das amostras de urina. Conclusão: Encontramos, no presente estudo, uma alta taxa de excreção de VJC, VBK e excreção simultânea em pacientes HIV+. Ainda, esses resultados diferem de outros disponíveis na literatura.

\section{COMPETING INTERESTS}

The authors declared that there are no competing interests.

\section{FUNDING}

Fundação de Amparo à Pesquisa do Estado de São Paulo (FAPESP), Grant \# 2007/04681-1 and Conselho Nacional de Desenvolvimento Científico e Tecnológico (CNPQ), Grant \#301339/2009-9.

\section{ACKNOWLEDGEMENTS}

We thank Prof. Dr. Expedito José de Albuquerque Luna for the support with the statistical analyses.

\section{REFERENCES}

1. Agostini HT, Yanagihara R, Davis V, Ryschkewitsch CF, Stoner GL. Asian genotypes of JC virus in Native Americans and in a Pacific Island population: markers of viral evolution and human migration. Proc Natl Acad Sci U S A. 1997;94:14542-6.

2. Antinori A, Ammassari A, Giancola ML, Cingolani A, Grisetti S, Murri R, et al. Epidemiology and prognosis of AIDS-associated progressive multifocal leukoencephalopathy in the HAART era. J Neurovirol. 2001;7:323-8.

3. Antonsson A, Green AC, Mallitt KA, O'Rourke PK, Pawlita M, Waterboer T, et al. Prevalence and stability of antibodies to the $\mathrm{BK}$ and JC polyomaviruses: a long-term longitudinal study of Australians. J Gen Virol. 2010;91:1849-53.

4. Arthur RR, Dagostin S, Shah KV. Detection of BK virus and JC virus in urine and brain tissue by the polymerase chain reaction. J Clin Microbiol. 1989;27:1174-9. 
NALI, L.H.S.; CENTRONE, C.C.; URBANO, P.R.P.; PENALVA-DE-OLIVEIRA, A.C.; VIDAL, J.E.; MIRANDA, E.P.; PANNUTTI, C.S. \& FINK, M.C.D.S. - High prevalence of the simultaneous excretion of polyomaviruses JC and BK in the urine of HIV-infected patients without neurological symptoms in São Paulo, Brazil. Rev. Inst. Med. Trop. Sao Paulo, 54(4): 201-5, 2012.

5. Astrom KE, Mancall EL, Richardson EP Jr. Progressive multifocal leuko-encephalopathy; a hitherto unrecognized complication of chronic lymphatic leukaemia and Hodgkin's disease. Brain. 1958;81:93-111.

6. Barouch DH, Faquin WC, Chen Y, Koralnik IJ, Robbins GK, Davis BT. BK virusassociated hemorrhagic cystitis in a Human Immunodeficiency Virus-infected patient. Clin Infect Dis. 2002;35:326-9.

7. Behzad-Behbahani A, Klapper PE, Vallely PJ, Cleator GM, Khoo SH. Detection of BK virus and JC virus DNA in urine samples from immunocompromised (HIV-infected) and immunocompetent (HIV-non-infected) patients using polymerase chain reaction and microplate hybridisation. J Clin Virol. 2004;29:224-9.

8. Berger JR, Kaszovitz B, Post MJ, Dickinson G. Progressive multifocal leukoencephalopathy associated with human immunodeficiency virus infection. A review of the literature with a report of sixteen cases. Ann Intern Med. 1987;107:78-87.

9. Berger JR, Major EO. Progressive multifocal leukoencephalopathy. Semin Neurol 1999;19:193-200.

10. Brooks BR, Walker DL. Progressive multifocal leukoencephalopathy. Neurol Clin. 1984;2:299-313

11. Brown P, Tsai T, Gajdusek DC. Seroepidemiology of human papovaviruses. Discovery of virgin populations and some unusual patterns of antibody prevalence among remote peoples of the world. Am J Epidemiol. 1975;102:331-40.

12. Chou Q, Russell M, Birch DE, Raymond J, Bloch W. Prevention of pre-PCR mis-priming and primer dimerization improves low-copy-number amplifications. Nucleic Acids Res. 1992;20:1717-23.

13. Cinque P, Koralnik IJ, Gerevini S, Miro JM, Price RW. Progressive multifocal leukoencephalopathy in HIV-1 infection. Lancet Infect Dis. 2009;9:625-36.

14. Daniel DC, Wortman MJ, Schiller RJ, Liu H, Gan L, Mellen JS, et al. Coordinate effects of human immunodeficiency virus type 1 protein Tat and cellular protein Puralpha on DNA replication initiated at the JC virus origin. J Gen Virol. 2001;82:1543-53.

15. Dorries K, ter Meulen V. Progressive multifocal leucoencephalopathy: detection of papovavirus JC in kidney tissue. J Med Virol. 1983;11:307-17.

16. Drachenberg CB, Hirsch HH, Papadimitriou JC, Gosert R, Wali RK, Munivenkatappa $\mathrm{R}$, et al. Polyomavirus BK versus JC replication and nephropathy in renal transplant recipients: a prospective evaluation. Transplantation. 2007;84:323-30.

17. Egli A, Infanti L, Dumoulin A, Buser A, Samaridis J, Stebler C, et al. Prevalence of polyomavirus BK and JC infection and replication in 400 healthy blood donors. J Infect Dis. 2009; 199:837-46.

18. Fink MC, Penalva de Oliveira AC, Milagres FA, Vidal JE, Picerno-Pouza AF, Duarte Neto A, et al. JC virus DNA in cerebrospinal fluid samples from Brazilian AIDS patients with focal brain lesions without mass effect. J Infect. 2006;52:30-6.

19. Flaegstad T, Traavik T, Kolmannskog S, Stokland T. BK virus infection in children with cancer: serological response studied by haemagglutination inhibition, neutralization, and IgG- and IgM-class specific ELISA tests. J Med Virol. 1988;24:33-44.

20. Gardner SD. Prevalence in England of antibody to human polyomavirus (B.k.). Br Med J. 1973;1(5845):77-8

21. Grabowski MK, Viscidi RP, Margolick JB, Jacobson LP, Shah KV. Investigation of prediagnostic virological markers for progressive multifocal leukoencephalopathy in human immunodeficiency virus-infected patients. J Med Virol. 2009;81:1140-50.

22. Heritage J, Chesters PM, McCance DJ. The persistence of papovavirus BK DNA sequences in normal human renal tissue. J Med Virol. 1981:8:143-50.

23. Holman RC, Török TJ, Belay ED, Janssen RS, Schonberger LB. Progressive multifocal leukoencephalopathy in the United States, 1979-1994: increased mortality associated with HIV infection. Neuroepidemiology. 1998;17:303-9.
24. Hoppe BL, Conti-Tronconi BM, Horton RM. Gel-loading dyes compatible with PCR Biotechniques. 1992;12:679-80.

25. Jin L. Rapid genomic typing of BK virus directly from clinical specimens. Mol Cell Probes. 1993; 7:331-4

26. Kinnaird AN, Anstead GM. Hemorrhagic cystitis and possible neurologic disease from BK virus infection in a patient with AIDS. Infection. 2010;38:124-7.

27. Kitamura T, Kunitake T, Guo J, Tominaga T, Kawabe K, Yogo Y. Transmission of the human polyomavirus JC virus occurs both within the family and outside the family. J Clin Microbiol. 1994;32:2359-63.

28. Knowles WA, Pillay D, Johnson MA, Hand JF, Brown DW. Prevalence of long-term BK and JC excretion in HIV-infected adults and lack of correlation with serological markers. J Med Virol. 1999·59:474-9.

29. Knowles WA, Pipkin P, Andrews N, Vyse A, Minor P, Brown DW, et al. Populationbased study of antibody to the human polyomaviruses BKV and JCV and the simian polyomavirus SV40. J Med Virol. 2003;71:115-23.

30. Krumbholz A, Bininda-Emonds OR, Wutzler P, Zell R. Phylogenetics, evolution, and medical importance of polyomaviruses. Infect Genet Evol. 2009;9:784-99.

31. Krumbholz A, Zell R, Egerer R, Sauerbrei A, Helming A, Gruhn B, et al. Prevalence of BK virus subtype I in Germany. J Med Virol. 2006;78:1588-98.

32. Ledesma J, Munoz P, Garcia de Viedma D, Cabrero I, Loeches B, Montilla P, et al. $\mathrm{BK}$ virus infection in human immunodeficiency virus-infected patients. Eur J Clin Microbiol Infect Dis. 2012;31:1531-5.

33. Machado DM, Fink MC, Pannuti CS, Succi RC, Machado AA, do Carmo FB, et al. Human polyomaviruses JC and BK in the urine of Brazilian children and adolescents vertically infected by HIV. Mem Inst Oswaldo Cruz. 2011;106:931-5

34. Markowitz RB, Thompson HC, Mueller JF, Cohen JA, Dynan WS. Incidence of BK virus and JC virus viruria in human immunodeficiency virus-infected and -uninfected subjects. J Infect Dis. 1993;167:13-20

35. Matos A, Duque V, Beato S, da Silva JP, Major E, Melico-Silvestre A. Characterization of JC human polyomavirus infection in a Portuguese population. J Med Virol 2010;82:494-504.

36. Polo C, Pérez JL, Mielnichuck A, Fedele CG, Niubo J, Tenorio A. Prevalence and patterns of polyomavirus urinary excretion in immunocompetent adults and children. Clin Microbiol Infect. 2004;10:640-4.

37. Rodrigues C, Pinto D, Medeiros R. Molecular epidemiology characterization of the urinary excretion of polyomavirus in healthy individuals from Portugal--a Southern European population. J Med Virol. 2007;79:1194-8

38. Sundsfjord A, Flaegstad T, Flo R, Spein AR, Pedersen M, Permin H, et al. BK and JC viruses in human immunodeficiency virus type 1-infected persons: prevalence, excretion, viremia, and viral regulatory regions. J Infect Dis. 1994;169:485-90.

39. Tan CS, Koralnik IJ. Progressive multifocal leukoencephalopathy and other disorder caused by JC virus: clinical features and pathogenesis. Lancet Neurol. 2010;9:425-37.

40. Tsai RT, Wang M, Ou WC, Lee YL, Li SY, Fung CY, et al. Incidence of JC viruria is higher than that of BK viruria in Taiwan. J Med Virol. 1997;52:253-7.

41. Vidal JE, Fink MC, Cedeno-Laurent F, Delbue S, Ferrante P, Dauar RF, et al. BK virus associated meningoencephalitis in an AIDS patient treated with HAART. AIDS Res Ther. 2007;4:13

42. Zhong S, Zheng HY, Suzuki M, Chen Q, Ikegaya H, Aoki N, et al. Age-related urinary excretion of BK polyomavirus by nonimmunocompromised individuals. J Clin Microbiol. 2007;45:193-8.

Received: 27 January 2012

Accepted: 25 May 2012 


\section{Revista do Instituto de Medicina Tropical de São Paulo on line.}

Publications from 1987 to the present data are now available on:

http://www.scielo.br/rimtsp

PAST ISSUES 1959-1989 (PDF)

www.imt.usp.br/portal/

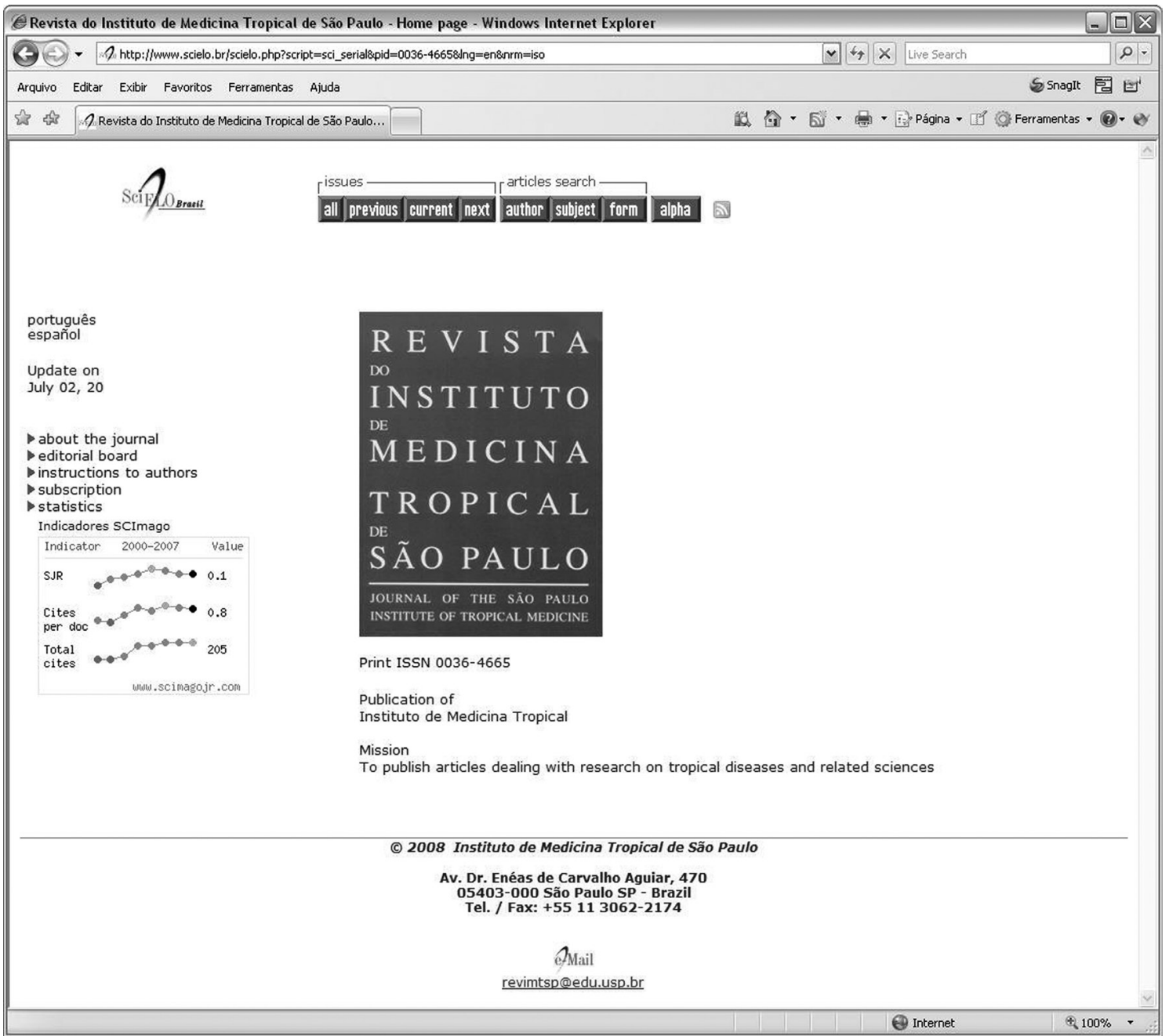

SciELO - The Scientific Electronic Library OnLine - SciELO is an electronic virtual covering a selected collection of Brazilian scientific journals.

The library is an integral part of a project being developed by FAPESP - Fundação de Amparo à Pesquisa do Estado de São Paulo, in partnership with BIREME - the Latin American and Caribbean Center on Health Sciences Information.

SciELO interface provides access to its serials collection via an alphabetic list of titles or a subject index or a search by word of serial titles, publisher names, city of publication and subject.

The interface also provides access to the full text of articles via author index or subject index or a search form on article elements such as author names, words from title, subject and words from full text.

FAPESP/BIREME Project on Scientific Electronic Publications Latin American and Caribbean Center on Health Sciences Information

Rua Botucatu 862 - 04023-901 São Paulo, SP - Brazil

Tel. (011) 5576-9863

scielo@bireme.br 